\title{
Minute Times Nanomole per Liter per Kilogram per Meter Squared
}

National Cancer Institute

\section{Source}

National Cancer Institute. Minute Times Nanomole per Liter per Kilogram per Meter

Squared. NCI Thesaurus. Code C111270.

Minutes times nanomoles per liter, divided by kilograms per meter squared. 